\title{
Towards a Non-human Speciophilosophy
}

\author{
Enrico Giannetto \\ (Università degli Studi di Bergamo; enrico.giannetto@unibg.it) \\ ORCID: 0000-0002-6784-2048
}

\begin{abstract}
After the publication of Jaques Derrida's book, L'animal que donc je suis, anti-speciesism has been looking for a theoretical foundation for its ethical content. In my opinion, the defect of all these philosophical perspectives is that they still reduce animals to objects of human philosophy. Here, I develop a new framework in which animals are considered as subjects of their own philosophy. In analogy to the concept of ethnophilosophy, the concept of speciophilosophy is here introduced $(\S 1, \S 3)$. The different ways of thinking between humans and other animals are outlined, by explaining the difference between verbal reasoning and thinking through images $(\S 2)$. Human philosophies are shown to be anthropocentric ideologies, related to carnivorism $(\S 4, \S 8)$. Subsequently, animal speciophilosophies are discussed (§6) and a dialogical symphilosophein ( $(5)$ among all living beings is proposed to be the extension of the so-called philosophy of dialogue. Finally, it is shown how this perspective was present in the original Christian ethics $(\S 7, \S 9, \S 10)$.
\end{abstract}

Keywords: Animals; animal philosophy; modes of thought; philosophy of dialogue; anti-speciesist ethics; Christian ethics; reverence for life; Jacques Derrida.

\section{Introduction}

For many years, anthropological studies have been acknowledging the need to introduce the concepts of ethnomedicine, ethnomathematics and, more in general, of ethnosciences ${ }^{1}$. This implies the need for a concept of ethnophilosophy: even philosophical tradition, the most defining trait of Western culture, must no longer be considered as a uniquely Western product. There is no reason to deny Eastern thought the title of Eastern philosophy, no matter how much it diverges from the European way of thinking.

In this article, I would like to propose a new understanding of human thinking. A distinction can be made between no less than two modes of thought: thinking through images and thinking through words, that is, visual thinking and verbal reasoning. These two modes of thought correspond to what Aristotle respectively defined as noetic thought and dianoetic thought (Calogero 1967/2012, 1968).

Thought cannot be reduced to verbal reasoning. This also implies that non-human animals do think as well: they are capable of a visual mode of thought. Non-human animals 
also possess specific verbal languages to communicate with one another. The specific character of human thinking is nothing but a synthesis of visual thinking and verbal language into verbal reasoning: this mode of thought has embedded visual thinking into a dialogical praxis, thereby allowing for abstractions from life in the form of written texts.

Western philosophy, at least after Socrates, has developed through written culture, but other ethnophilosophies have been developing organically, with life itself. If this is true, the concept of speciophilosophy may be introduced: there exists a multitude of philosophies not only as related to different human ethnic groups, but to different species that hold different worldviews, different ways of thinking and living.

Understanding non-human beings is impossible within the framework of human philosophy, as it will imply some kind of dialogue with non-human beings, achieved through an experience of participant observation aimed at understanding and learning animal philosophies. One school of ancient philosophy was called Cynicism only out of a sense of disdain. However, the time is ripe to truly understand animal philosophies, to respect all other living beings and even to improve our way of thinking and living.

\section{Ethnophilosophy}

For many years, anthropological studies have been acknowledging the need to introduce the concepts of ethnomedicine, ethnomathematics and, more generally, ethnosciences (Ascher 1991; Erickson 2008; Scheps \& Arom 1993). This implies the need for a concept of ethnophilosophy (see also Garfield \& Edelglass 2014; Hountondji 1996; Kearney 1984; Osha 2011; Pulak \& Chandan 2005; Radin 2003; Sefa Dei 2011; Sefa Dei et al. 2000; Worsley 1997). Even philosophical tradition, the most defining trait of Western culture, must no longer be considered as a uniquely Western product. There is no reason to deny Eastern thought the title of Eastern philosophy. Indeed, Western tradition has often regarded Eastern thought as too linked to mythical or religious reasoning to be defined as a "philosophy" (Husserl 1936/1954), and there certainly exist differences between Eastern and Western thought. However, Western thought shows no clear detachment from myth or religion, either: Parmenides wrote poetry and Plato used myths. One must also recognize that every philosophical or scientific concept has mythical roots: space and time, force and energy, truth and rectitude, beauty, justice and love are forms of secularized deities (Santillana \& von Dechend 1969).

Thus, one can speak of philosophy, or more accurately of ethnophilosophy, in relation to every facet of humankind, every current of thought, every understanding of life and of the world.

\section{Verbal Reasoning and Thinking through Images}

What does it actually mean to think? Here, I would like to propose a new 
understanding of human thinking. A distinction can be made between no less than two human modes of thought: thinking through images and thinking through words, in other words, visual thinking and verbal reasoning. These two modes of thought correspond to what Aristotle defined respectively as noetic thought and dianoetic thought (Calogero 1968). As a matter of fact, all ancient Greek philosophies can be understood in terms of the relationship between visual thinking and verbal reasoning (Calogero 1967/2012). Mythical thinking is essentially visual thinking, whereas Western philosophical thought is essentially verbal reasoning. This shift can be traced back to the transition from the iconic symbolism of ideograms and mythograms to an alphabetic, phonetic, linear writing system (Leroi-Gourhan 1964). Visual thinking is indeed a more complex mode of thought, as it is non-linear, non-sequential, and three-dimensional: it was the most ancient mode of thought, but it is also the form of future "parallel" (computer) thinking (Bailey 1996). Furthermore, although verbal reasoning is dominant in logic-linguistic thought, when one needs to think fast, one comes back to visual thinking, simply constructing a mental picture of the situation (Calogero 1960, Volume 1,12-24). Dreaming is a kind of visual and, more generally, "sensory" thinking. However, visual thinking is not merely a form of automatic or unconscious thought. Pure (ancient) geometrical thought is a kind of visual thinking: in this respect, mathematical thinking, for its correlation to a non-alphabetic, non-phonetic, non-linear writing system, represents a mode of thought entirely different from philosophical thinking. This contradicts the idea that thinking through images is a less rigorous mode of thought than verbal reasoning. A shape such as a circle is definite in that it has exact properties, which cannot be confused with the properties of another shape, such as a square. Furthermore, poetic imagery and visual arts are also examples of visual thinking, as painter René Magritte has shown.

\section{Non-human Animal Thinking and Speciophilosophy}

Thus, thinking cannot be reduced to verbal reasoning. This has many implications. The human presumption to be the sole being capable of thought has always been related to our definition of thought in terms of verbal reasoning. Thus, the most important implication is that, although they are not capable of verbal reasoning, non-human animals with a nervous system capable of vision must also be capable of visual thinking. Only through this consciousness of the primary visual character of thinking can one understand that thought does not manifest itself in human beings alone, and overcome the foundation on which anthropocentrism and speciesism have been erected.

Non-human animals also possess specific verbal languages to communicate with one another (Sebeok 1991). However, these animal languages appear starkly different from human language: they are strictly related to immediate, vital situations, they are not articulated in alphabetical phonemes, and they are totally devoid of conceptual abstractions. They are instead expressions of perception, of sensation, of feeling and 
affection, direct exchanges of vital information with no crystallization or accumulation of meaning in symbols or signs recorded in outside supports. Thus, these languages are not preserved in written culture: non-human animal culture is a kind of material culture characterized by non-written symbolism (see also Beck 1980; Bisconti 2008; Bonner 1983; Laland \& Galef 2009). Indeed, non-human animal languages are able to communicate perceptive, emotional-affective and cognitive experiences, but they never function as an autonomous elaboration of knowledge, independent from experience or anticipating experience, a function that Kant would define as human pure reason (cf. Kant 1787).

Thus, there exists an animal mode of thought which works through the internal association of images, a sort of inner ideation and vision. Any differences with human thought are simply differences in content and degree of elaboration; thus, there is no substantial difference between one and the other (Calogero 1960, Volume 3, 164-178, 196-213). Animal thinking is visual thinking, a mode of thought linked to the senses and very different from human language-based verbal reasoning: unlike in human beings, in non-human animals there is no abstract synthesis between the intellective and communicative functions, through means of which language becomes the support for the articulation of thought.

In philosophical terms, non-human animal thinking is a kind of noetic thinking, related to vision and intuition through images, and not dianoetic thinking, which is based on human language. Non-human animal thinking has no linguistic or conceptual abstraction, no analysis or synthesis of perceptive experience through vision: such abstractions are useless for life in its immediacy and are related mostly to specific human projects of dominion over Nature and other living beings.

The specific character of human thinking is nothing but a synthesis of visual thinking and verbal language into verbal reasoning: this mode of thought has embedded visual thinking into a dialogical praxis, and successively in written text, thus also allowing for abstractions from life.

Western philosophy, at least after Socrates, has developed through written culture, but other ethnophilosophies have been developing organically with life itself. That is, these ethnophilosophies are not philosophies elaborated through verbal reasoning within a written language: they are indeed, both literally and essentially, a worldview, a Weltanschauung, a "pre-understanding"2 gained through the very act of living, and not a rational representation of the world (Weltbild). Indeed, as already emphasized at least by Leibniz's and Nietzsche's philosophies, one can attribute a perspective worldview to all non-human animals, ${ }^{3}$ if not to every last monad that makes up part of the universe. If

2 Cf. Heidegger's lecture Die Zeit des Weltbildes (Heidegger 1950).

3 Cf. Nietzsche's lectures Die vorplatonischen Philosophen as published in Holzer et al. (1913, Volume 3). The same lecture was re-published also in Oehler et al. (1924, Volume 4): Here Nietzsche refers to the work of biologist Karl Ernst Ritter von Baer (1792-1876). 
this is true, the concept of speciophilosophy may be introduced: there exists a multitude of philosophies, not only as related to different human ethnic groups, but to different species that hold different worldviews, different ways of thinking and living.

Heidegger (1983) wrote that non-human animals are poor in the world, or worldless, but Heidegger had reduced the world to human existence, a phenomenon which holds meaning for human beings alone (Heidegger 1927/1977; 2001) ${ }^{4}$. This metaphysical conceptualization is entirely anthropocentric (see also Acampora 2006; Calarco 2008; Derrida 2006). Non-human animals are poor only in the human world: they experience another perception of the world, that is, a perception of another world. If moths and mice are incapable of reading human literature (moths and mice, however, understand books are derived from wood, rags or grasses), what could a human being hope to understand about the world of moths and mice? The human world is above all a cultural world, a world of concepts and signs: human beings have lost sight of the actual world, Nature has been obscured by culture. We look for conceptual meaning within every event and we live within the illusion that only our human language may enlighten us to reality itself, that is, we look at language as the house of being (Heidegger 1959). However, our conceptual, denotative language and our verbal reasoning have caused us to lose sight of Nature, to hide individual living beings behind abstractions and generalizations: in our languages, the single being is a determination (i.e., by article) of the universal concept of species, we do not consider a single mouse with its joys and sorrows, but only a sample of the concept of "mouse". As such, the sign has erased the being.

\section{Human Rational Philosophies as Projects of Dominion and Anthropocentric Ideologies}

Not only does Western philosophy represent a limited viewpoint, but the entirety of human philosophies also only constitutes a particular species of philosophy. What characterizes human philosophies as a species? When our words are deprived of their living character, tied to their communicative function and evocative (poetic) or performative power, and assume a purely descriptive, denotative role, language replaces the actual world with a rational reconstruction of it: the actual world is substituted for a world of conceptual signs. In a deeper fashion than the Cartesian worldview, semiotization and "mathematization" reduce the world to a rational-linguistic reconstruction, a "world of concepts", a substitutive representation ${ }^{5}$.

Why did this substitution occur? There are two major reasons: to project human dominion over Nature and other living beings or to legitimate it through an anthropocentric representation of the world. These goals may be consciously declared or unconsciously

4 That edited by F. W. von Herrmann (1977) was the first edition with marginal glosses of the so called Hüttenexemplar by Heidegger (see also Giannetto 2010).

5 Cf. Heidegger's 1938 lecture Die Zeit des Weltbildes as published in Heidegger (1950). 
assumed.

Human philosophies are, for the most part, philosophies of victorious human apex predator, they are the semiotic devouring of other living beings, no longer forms of symbolism but of metabolism. Human philosophies are not only ideologies of a dominant class over other classes (Lukacs 1923), but also and more deeply ideologies of the dominant human species over other living beings, within a struggle not for existence but for supremacy, a struggle initiated by mankind itself. Human philosophies are ideologies because they represent and plan what is essentially a matter of dominance as a necessary condition of human existence. In this deeper ideological sense, all human philosophies are speciesist.

Thus, any critique of human philosophy cannot be but a destruction of human rational philosophies, because within their framework and that of verbal reasoning, language has been reducing the world and every living being to a world of signs and concepts: what Heidegger (1950) attributes to Descartes' modern perspective is only the explicit conscious form of a reduction intrinsic to verbal reasoning. Humans, as other Simians, like to simulate, but humans have actualized external simulations as theoreticalconceptual or mathematical-experimental models to dominate Nature and other living beings. Any critique of reason cannot be but a destruction of reason, a destruction of concepts through concepts. Understanding of other living beings as well as the world can only emerge negatively through the destruction of the representative function of language, which constitutes a deformation of reality: this destruction can only be actualized through poetic thinking, through a poetic philosophy. Understanding other living beings, whether human and non-human, will only be possible through dialogue, that is, by using language in its original dialogical function; and, as there exist different human and non-human languages, it is fundamental to understand each different language by understanding each different worldview, that is, each different way of life.

\section{Towards a Symphilosophein among Different Living Beings}

This implies that one must give up any rational philosophy, any theoretical logos, by reconstituting philosophy as dialogical living philosophy, that is, philosophy as a praxis of dialogos. In any case, every human philosophy as mere human logos is a human speciophilosophy, one that cannot boast any pseudo-universal privilege to understand other living beings.

A human philosophy as a dialogical praxis, that is a philosophy of dialogue (derived from Socrates and Feuerbach) (see also von Balthasar 1973; Böchenhoff 1970; Buber 1984; Casper 2002) has been exposed by Guido Calogero in a non-ontological, nonmetaphysical form. Calogero $(1950 ; 1962)$ also suggested the potential non-limitedness of the community of dialogue: dialogue has limits only insofar as one decides to interrupt dialogue by turning towards violence and dominion. It is absolutely necessary to interrupt 
human murder, phagocytosis, violence, dominion, exploitation, imprisonment of other living beings, to liberate non-human beings and to open before them the possibility of a peaceful life as well as that of dialogue. Thus, one may consider a symphilosophein among human and non-human living beings as a praxis of dialogue, that is, a form of Calogero's philosophy of dialogue extended to interspecies dialogue. This means that we as human beings must give up our way of living as carnivorous predators, we must change our way of life in a continuous effort to understand other living beings through actual universal love, through ethical reverence for life (Schweitzer 1923, Volumes 1-2).

We have no need of an onto-logical or biological definition or description of what a human or non-human being is: it is an ethical choice to show reverence for every individual life, one that may truly be recognized only through an ethical act. In contrast, ontological or biological definitions or descriptions, being reductions to objects, signs and concepts, are symbolically violent acts. We have a need for hermeneutical ethics, that is, a hermeneutical ethical praxis. If understanding is an ethical act and not a logical, gnoseological, ontological and metaphysical act, the whole of philosophy is ethics. We cannot understand without love and we cannot love without understanding: in this context, love means above all respect for otherness. We must nurture an absolute will to dialogue and become conscious of our living nature as universal Eros/Agàpe (Marcuse 1955), which, independently from any ontological undecidable assumptions, wishes to consider all other living beings as interlocutors as well as subjects (persons without human cultural distortions) of life and love and not as things to be used as means to our ends.

Such dialogue is always possible, because it should not be confined within our human language and it can exist even if our understanding is ever reciprocally partial and defective. There is no universal language and no translation is ever perfect (we often speak of the incommensurability of languages). However, there exists a language of gestures, of eyes and looks, of acts of love, of touch, body and sensation, which has no need for translation.

Thus, understanding non-human beings will not be possible within a human rational philosophy, but it will imply some kind of dialogue with non-human beings, by living an experience of "participant observation" (see Malinowski 2013) (extended from anthropology to ethology), to learn to understand different animal philosophies, different animal worldviews. We must reconsider ethology not as a scientific, detached discipline, but rather as an ethical praxis which implies actual participation as com-passion.

Understanding other living beings means understanding other living beings' modes of thought, that is, understanding their "philosophy of life", which is one with their life: it means sharing their life through love and active care for them.

A paradigm shift is called for: we must cease to elaborate human philosophy (or science) on other animals or other living beings, and we must seek a philosophy of pandas or elephants, a philosophy of jasmine or roses, to understand their own vital and ethical 
consciousness of the world. I believe that no living being was born a carnivorous predator, but became such by some choice of diet at some existential bifurcation (to survive by eating meat or die): there is no absolute nature/essence of living beings, but an evolution of them. Epigenetics (the study of heritable phenotype changes that do not involve alterations in the DNA sequence) now explain that phenotypic variations can switch genes on and off, thus producing inheritable alterations (Carey 2011). Carnivorous predators are not such by "nature", but by evolution: carnivorism can be explained as an epigenetic effect, one that may be modified by a new way of living and eating. We must recognize that other animals, such as carnivorous predators like cats and dogs, have made a violent pact with human beings to share the fruits of the tree of the knowledge of good and evil, to share the food of dominance, and have thereby distorted their philosophy of life into violence before us; but we must also recognize that many other living beings have never left the vital dimension of Eros/Agàpe.

Understanding this fact would mean understanding our own human philosophy in a new light, to see it as one with our life and no longer as theoretical, disinterested contemplation, as detached, distant vision, as indifference to what happens to other beings and to the world.

\section{How Can We Understand Non-human Speciophilosophy?}

How can we catch a glimpse of a non-human speciophilosophy? Can we develop this kind of understanding through human philosophy itself? Ancient philosophy sometimes appeared to imply a non-human worldview and way of life. One school of ancient philosophy was called Cynicism, but only out of a sense of disdain (Calogero 1933). If Cynicism had truly been the philosophy of living dogs, it would never have contemplated the ideals of self-sufficiency, non-compassion, indifference to the world and to other lives. It would never have postulated the eudemonistic, egoist absolute value of individual happiness, from which the non-ethical drift we today associate with the word "cynicism" followed. The analogy was limited to Diogenes' way of living as a stray dog or to a generic impulse to live according only to Nature, free of cultural constraints.

However, the time is ripe to truly understand animal philosophies, to respect all other living beings and even to improve our way of thinking and living. We must begin to learn from other animals, because we have lost our way as human beings.

Primeval Christianity has been associated by some historians with a sort of "Hebrew Cynicism", in particular with regard to nomadism, "living as stray dogs". However, any analogy with Greek Cynicism is misleading, because self-sufficiency (Calogero 1947), indifference or lack of compassion have no place in the life and teachings of Jesus. Jesus invited his followers to practice active love, to actively care for others, to be close to all beings within active love without difference of ethnic background or species (Luke 10: The neighbor is not an object of love, but a subject of love; the person who loves becomes 
neighbor to any other), a teaching that culminated in suffering to death for the happiness of others and for the actualization of the Kingdom of God: here, according to the Bible (Isaiah 11:6-9), the wolf and the lamb will live together, without reciprocal violence, without devouring, among all living beings; in Mark 1:13 it is said that Jesus lived together with wild beasts.

Another metaphorical suggestion to understand different non-human speciophilosophies was given by Nietzsche (Acampora \& Acampora 2003). Nietzsche indeed exalted a "philosophy of predators" who impose their will to power: he put value not in the ethically inconsequential fact of the common origin of all living beings as stated in the theory of evolution, but rather in the identification of the struggle for existence with the evolutive factor, even if in a non-mechanistic fashion (Giannetto 2010, Chapter 5). However, in the struggle for life he did not take the side of the beings who adapt themselves to the environment and live for their conservation and survival, but rather of those who live without fear of death and extinction and express their lust for power and dominance to the maximum degree ${ }^{6}$. Thus, Nietzsche wrote about Christianity as a "philosophy of life proper to gregarious lambs" for its meekness in the wake of the teachings of Jesus.

\title{
7. Primeval Christianity and the Philosophy of Lilies
}

On the contrary, Oscar Wilde gave a radical interpretation of the verses of Matthew 6:25-34 in his De Profundis ${ }^{7}$ : Jesus urged human beings to live like lilies of the field! Wilde

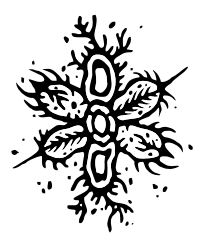
wrote that one must live following what we could call the "philosophy of flowers"; and, we could add, following the "philosophy of the fowls of the air". It is essential to give a new translation of these verses from the old Syriac and Palestinian Aramaic versions of the Matthew Gospel, which I believe constitute the original text on which the Greek text was translated (numbers indicate verses) (also see Miniscalchi Frizzo 1861 and Wilson 2003) ${ }^{8}$ :

\begin{abstract}
${ }^{25}$ Indeed, I say unto you, Take no thought for your life, what ye shall eat, or what ye shall drink; nor yet for your body, what ye shall put on. Is not the life more than food, and the body than raiment? ${ }^{26}$ Behold the fowls of the air: for they sow not, neither do they reap, nor gather into barns; yet your Father of heaven giveth them food. $b$ Shall ye not receive more than they? ${ }^{27}$ Which of you by taking thought can add one hour to his/her life? ${ }^{28}$ And why take ye thought for raiment? Consider the lilies of the field, how they grow; they toil not, neither do they spin. ${ }^{29}$ And yet I say unto you, That even Solomon in all his glory was not arrayed like one of these. ${ }^{30}$ Wherefore, if God so clothe the grass of the field, which to day is, and to morrow is cast into the oven, shall God not care of you, 0 ye of little faith? ${ }^{31}$ Therefore take no thought, saying, What shall we eat? or, What shall we drink? or, Wherewithal shall we be clothed? ${ }^{32}$ For after all these things do the Gentiles
\end{abstract}

6 Cf. Nietzsche's essay Jenseits von Gut und Böse - Vorspiel einer Philosophie der Zukunft (1886), as well as Zur Genealogie der Moral, Eine Streitschrift (1887), as published in Colli and Montinari (1980).

7 Oscar Wilde wrote De Profundis in 1897 in prison and the first edition was published in 1905; the various versions and the original manuscript have been published in Small (2005, Volume 2).

8 However, I will give a new translation (a variation of the KJV version), because both these translations in Western languages were made to agree with the Greek text. 
seek. However, your Father of heaven knoweth that ye have need of all these things. ${ }^{33}$ But seek ye first the kingdom of God, and its righteousness; and all these things shall be added unto you. ${ }^{34}$ Take therefore no thought for the morrow: for the morrow shall take thought for the things of itself. Sufficient unto the day is the evil thereof (modified King James version) (Matthew Gospel, 6:25-34).

These verses, read together with Leviticus 25:11-12 and 19-20, allow us to understand the teaching of Jesus: that one should always follow the practices which Leviticus dictated be followed only in occasion of the Jubilee. We no longer need to cultivate Earth's soil, no longer need agriculture, and we can completely abandon ourselves to God for our own nutrition, by limiting it to what a non-cultivated soil spontaneously offers. However, Jesus adds a comparison to the fowls of the air: human ethical praxis must learn from the ethical praxis of the life of birds. Only a poet such as Oscar Wilde could understand the implications of these verses so completely, and in De Profundis he writes that we must live like flowers, like the lilies of the field which do not toil and do not spin. Jesus's words show that birds' and flowers' ethical praxis and faith in God are greater than those of humans! Indeed, verse 6:26b as usually translated (Are ye not much better than they?), could seem to confirm human superiority in the eyes of God. However, one can read the original Aramaic text of the Vetus Syra (Cureton's text) to discover that the common translation is deformed by an anthropocentric perspective: the Gospel's text states simply that we as human beings will have more food than birds, because their nutrition is more limited to certain plant species. According to 6:28, we as human beings should not toil nor spin, that is, we should not work the soil for clothing and ornaments beyond food. All plant species are naturally magnificent without any cultivation and not even Solomon in all his glory was as adorned as one of the lilies. Looking for ornament is vanity in the literal sense of the word, because it is a vain task. We will never be able to surpass the beauty of flowers. Pulling them out of the soil or killing them to decorate ourselves or our houses is vain and a sign of envy. We humans cannot surpass or even reach their beauty. As for verse 30, which centers on the grass of the fields, much humbler than lilies, depicts God as less dismissive of the diminutive plant than the usual anthropocentric translation would imply (Wherefore, if God so clothe the grass of the field, which to day is, and to morrow is cast into the oven, shall he not much more clothe you, O ye of little faith?).

Indeed, the original Aramaic text states that even what is destined to be food for mankind (what will be cast into the oven) - and here is an implicit contrast with the fowl of the air which may never be considered as food for human beings (thus clarifying the fact that Jesus considered a vegan diet to be suitable for human beings) ${ }^{9}$ - is clothed by God with more splendor than the most powerful human king, who has made his clothes out of the cultivated, spun product of plants and silkmoths; and God will clothe us naturally without any need of spun materials, without any need to kill silkmoths: God will clothe us

9 That Jesus preached a vegan diet is shown by some agrapha (Asin y Palacios 1988/1990; Deleanu 2002, 25-35, 48). 
with the glory of heaven and of the Kingdom of God, because God takes care, God is Care for the whole of creation, for every creature.

Kierkegaard (1849/2016) also tried to give a philosophical, as well as a theological, content to these verses, but in a questionable way: he states that, while mankind does not know how to live in the present and in the instant, this is what the birds of the sky and flowers of the field do and what should teach to a human being. Following Kierkegaard, non-human beings are devoid of conscience and thus are also deprived of the sense of time. ${ }^{10}$ However, this is not true: they are not devoid of conscience, but only of discursive reason; nor do they lack the sense of time, but rather they live it fully, authentically, without binding fixations on the past and without distressing protrusions on the future life: they do not live like human beings determined by the anguish and non-acceptance of death which implies a violent behaviour.

If the birds of the sky and the flowers of the field lack this anguish of tomorrow and death, they too certainly suffer and do not live in an unconditional joy that Kierkegaard attributes to them. Only that the joy of all the little things in life is not ruined by the torment of tomorrow and death, and the suffering of everyday life is not amplified by that torment.

Kierkegaard then contrasts human silence with the silence of the birds of the sky and the flowers of the field: learning their silence would be tantamount to learning to keep silent and to understand that praying is not speaking and not just keeping silent but listening to God.

However, certainly the birds of the sky do not speak nor they are silent, but they

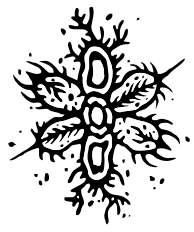
sing; and not even the grass and the flowers of the field are completely silent, but, swaying in the wind, with their own body they whisper: if the human language is above all of words-concepts, the animal language is of sounds-feelings and the language of the trees, of plants and flowers is a language of the body in being one with the forces of Nature such as wind, water, earth and sunlight.

Human beings no longer listen to Nature, but they only listen to the noise and to the chat of human discourses and they shun the silence in which we can hear "the voice of God". However, from birds and flowers we can learn not only silence, but also the deep song of life: music and human poetry are at their origin a mimesis of these songs.

Thus, Christianity has an original, still-hidden dimension of universal ethics. Indeed, primeval Christianity was not a theoretical philosophy or a metaphysical theology. Christianity has no speciesist ontology ${ }^{11}$ and with the Franciscan revolution, when it managed to free itself from the intellectualistic Greek metaphysics it had fallen into through a process of Hellenization, it began deconstructing any theoretical philosophy which, from an unbiased observation, reveals itself to reduce every living being to an object of human thought (Blumenberg 1974).

Today, Christianity can introduce mankind to a non-human and non-anthropocentric

10 Almost the same argument is present in relation to the wolf in Rowlands (2008).

11 A Christian theological anti-speciesism was elaborated by Linzey (1994). 
"living philosophy" in line with Jesus's appeal to the "philosophy of the fowls of the air and the lilies of the field", a philosophy of life which implies no possession, no property, no capital, no money, no violent work or dominance over Earth and its living beings, no violent phagocytosis of other beings: lilies do not fight for existence, as claimed by a deformed Darwinian predatory perspective; lilies live only by light and water being-inthe-soil, waving in the wind which moves the field into resonance. Lilies do not live by mere contemplation, but rather by opening their existence to the sun and to the sky.

Through this, we can understand what Heidegger has taken from Angelus Silesius: "a rose is a rose" (as a verse of Gertrude Stein also states), without any reason. A rose simply exists and a human being authentically exists only when their existence is like that of a rose Heidegger $(1957,73)$. Only here does Heidegger seem to overcome his anthropocentrism. We should live without any goal external to life itself: life is a goal in and of itself. Any conceptual, external, final cause dooms us deviate from an authentic life. A final cause is an ulterior (covert) motive, which is abuse, dominance, violence towards life. Life is a self-propagating process, and not any individual being: its impulse is love, Eros/Agàpe. Living is loving, because love is the only act with no ulterior motive. We love simply to love.

If an authentic human existence means existing like a rose, there is no hierarchy of living beings. There is no Heideggerian ontological difference between "Being" and beings, no substantial or essential difference among beings. There exists a variety of different beings: human beings, roses, horses and so on. There is no universal, unique "Being": "Being" is simply a hypostasis of a linguistic relation, firstoperated by Parmenides (Calogero 1936; 1967/2012; 1977): contingency is to be related to an irreducible multiplicity of beings. Understanding is a way of existing, that is, understanding is living: understanding is first of all understanding of other beings, reached through living dialogue.

\section{Carnivorism as the Origin of Violence and Verbal Thinking as Virtual Devouring}

Human philosophies are, for the most part, symbolic devouring. We are what we eat (Feuerbach 1866/1975, 357-407): if we eat other living animals and not the fruits of plants and trees, our flesh is constituted by the flesh of other living animals whose lives we have taken. As long as we remain carnivorous beings, our life is the result of violence and murder inflicted on other living animals: even the energy of a caress or of a kiss comes from this violence that constitutes our body, our very existence. Carnivorism is at the origin of inter-species and intra-species violence. We began by eating dead beings, then we turned ourselves into predators. As we became predators, we distorted our own pleasure function: we no longer feel pleasure only by eating to preserve our life, or by loving acts that transmit and create life, but as predators we associate the pleasure of eating to that of inflicting pain and death on living animals, whose status as objects of 
prey is such that the pleasure of inflicting pain can be entirely divorced from the act of eating itself (delaying - even ad infinitum - the act of eating itself to make pleasure grow). Thus, violence can give pleasure and can be practiced on other human beings as well. Eisler (1951) has thus explained the rise of sadism from carnivorism (see also Giannetto 2011), but indeed violence on every level can become an important part of our life, because our pleasure function has been distorted: violence can generate pleasure and increasing pleasure can be derived from the escalation of violence. Violence can be a selfsustaining and self-incrementing pleasure. In this way, hunting and fishing can become sports, hobbies. The aimless violence of the Nazis, like a sort of hunt for human beings, can thus be explained by this distortion of pleasure.

However, there is more: what we think is what we eat, and our mode of thought is part of our metabolism process, our devouring. Thinking is a process which is one with living. Thus, thought is tied to the pleasure of living and loving. When the pleasure of living is related to the devouring of other animals and the infliction of pain and death on other beings, thought becomes involved in devouring, in its strategies of predation and dominance; indeed, it becomes a symbolic devouring as well as a strategy for actual devouring. Thinking as verbal reasoning is no longer an expression of Eros/Agàpe, but an expression of Thanatos: Eros is transformed into extroverted Thanatos (Marcuse 1955). Human culture is not a simple sublimation of Eros, but a form of Thanatos, a form of virtual devouring. The analysis operated by verbal reasoning is akin to a dismemberment of the body, as flesh is torn to pieces disassembled first through predation and then through metabolism: devouring becomes the transcendental material "condition of possibility" to understand verbal reasoning.

However, from Freud's perspective, Eros seems to be circumscribed and forbidden in human life by a sociopolitical "principle of reality", which threatens its actualization. Eros/Agàpe appears to be confined only to the human sphere, because a biological "principle of reality" (the struggle for life and inter-species violence) seems to negate the extension of Eros to relationships with other living beings.

In contrast, Marcuse's perspective deconstructs this idea of reality and necessity. Such a construct is only the absolutization of a particular historical, economic-sociopolitical, evolutionary, anthropological and environmental condition, one which is indeed contingent. Marcuse makes a utopia real. This eschatological utopia of a future civilization, based on Eros/Agàpe and to be actualized through a multilevel revolution, builds its foundation in the memory of a primeval condition of non-carnivorous mankind. Indeed, since their appearance on the Earth, human beings have been thrown into an environmental condition of struggle for life: predatory animals have even hunted human beings. In such environmental context, even self-defense could have implied killing other preying animals. And mimesis, an imitation of these predators (i.e., wolves) could have transformed human beings into preying animals themselves. In any case, the partial or total lack of plant-based food within a particular environment could have induced human 
beings to negate Eros/Agàpe within the inter-species sphere for the aim of individual survival, thus giving rise to a new species of human beings as predators. Human beings began by satisfying their hunger with the flesh of other already dead animals, like other animals who transformed into preying animals (probably via epigenetic switching of genes) and were taken as models by humans; they subsequently developed an addiction to the death of other animals and became slaves to flesh food, which transformed them into predators and killers of other animals. A living being would naturally "look for" death only to make sufferance cease (Thanatos). However, the death instinct which was previously part of Eros has been extroverted through a cultural solution: becoming predators and eating the flesh of other animals. This was not a necessary transformation: humans or other animals could have returned to an environment full of plant-based food, and thus to a vegetarian diet via the switching of genes. We have to understand Darwinian evolution within a new synthesis with epigenetics. The struggle for life in the sense of animal preying is only actualized when a certain animal wants to maintain constant, longterm presence (in a timeframe relevant for nutrition) within an environment which does not allow for a vegetarian diet (i.e., arctic glaciers, desert zones or other environments unfit for human beings). There are fit- and unfit-for-vegetarian animal life environments: "natural selection" through struggle for life originally happens only within environments which are unfit for vegetarian animal life and therefore induce some animals to prey upon others.

The entire vital power an animal has to live and to be maximally happy is channeled

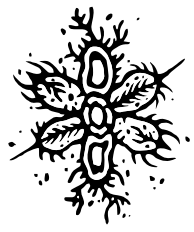
against other animals, which must be captured, killed and reduced to food: it becomes violence, destructive power to be exerted on other living beings. The life instinct is thus converted into a compulsion to kill other living beings. The body is converted into a sort of "war-machine" armed against other forms of life. Pleasure is converted into a feeling tied to violence. The non-acceptance of one's own individual death, even when living implies killing other living beings, externalizes the death instinct: it becomes a destructive instinct against others. The death instinct becomes autonomous from Eros/Agàpe and begins to oppose it: it becomes Thanatos. Life opposes death and so life opposes other lives. Life becomes enslaved by Thanatos and living is reduced to preying, to becoming an instrument of violence and death, will to power and supremacy, thus operating a distortion of pleasure, which becomes enslaved to dominance. The active principle of life, the vital energy of life, that is Eros, is not only subject to sublimation, but it is also converted into an instrument of death, into Thanatos. Rationalization thus represents not only the process of removing and repressing Eros, but also a legitimation of Thanatos. Existence becomes a struggle between Eros and Thanatos, and finally an ethical and political choice between life and death. Living an authentic, full human existence implies a revolution which allows for free non-human animal life.

We are no longer conscious of this violence, because our lives are, for the most part, devoid of the direct violence of preying: we find flesh (often in no recognizable 
form) to eat in supermarkets. Only a few human beings work as killers of non-human beings, and killing another animal implies a different kind of aggressive behaviour, due to the mechanization of violence and the act of killing using artificial machines. Thus, we become mostly unconscious of the origin of human violence in carnivorism (carnivorism is the original sin) (see Giannetto 2011) and we can be carnivorous without being directly violent (being non-aggressive), because we do not directly participate in the act of preying and killing. Paradoxically, this mechanization and industrialization of violence and killing - which has led to the highest level of violence and the systematic extermination of other living beings in human history - has also allowed for the detachment of carnivorism from violent behaviour, and with it the possibility of rejecting carnivorism itself in favor of a new, radically non-violent way of thinking.

\section{Primeval Christianity, Lambs and a New Understanding of the History of Philosophy}

The history of Western philosophy can be understood in terms of peace and war between Greek intellectualistic theoretical philosophy and Christian voluntarism based on ethics of active love (Calogero 1933). Here, our interest lies not in the theological or religious truth of Christianity, but in the historical deconstruction of theoretical philosophy which Christianity had been operating and operates whenever it recovers its revolutionary roots. Thus, like Nietzsche, we can consider Christianity in its Hellenized

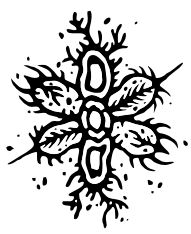
form as a sort of simplified (anthropocentric) Platonism, or we can consider primeval Christianity as a living philosophy that deconstructed Greek theoretical philosophy with all its dualisms between soul and body, human beings and non-human beings. Indeed, modern vegetarianism and veganism as well as modern forms of anti-speciesist ethics, stemming not from the ancient Greek or oriental eudemonistic ideal of individual (egoistic) perfection but rather from active love and care, are the historical effect of secularized Christian ethics, extended to all non-human animals.

What we have recognized within the original Christian worldview as a practical philosophy ${ }^{12}$, - that is, a conscious ethical praxis of unlimited reverence for every form of life in spite of all differences, a Christian faith which is nothing but a moral faith unto other living beings, a faith which identifies itself with a personal and cosmic Love towards all living beings, no longer considered as objects of our thought, but living subjects like us (Calogero 1928/1985) -, is indeed a neglected non-human philosophy, like the philosophy of lambs so disdained by Nietzsche.

Thus, the actual debate within Western philosophy is a symbolic debate among different, opposed, hidden non-human animal speciophilosophies: should we live like wolves (Eisler 1951), like blond predators ${ }^{13}$, or like lambs? We could employ a distinction

12 Regarding the original Christian ethics (see also Giannetto 2005, Chapter 5; 2006).

13 Cf. Nietzsche's essay Zur Genealogie der Moral, Eine Streitschrift (1887), as published in Colli 
introduced by Albert Schweitzer (1923): on the one hand, we have an affirmation of the world and life as the philosophy of non-carnivorous, non-predatory animals; on the other hand, we have a negation of the world and life as the philosophy of carnivorous, predatory animals. From this point of view, Schopenhauer's philosophy is only apparently (or only partially) nihilistic, by negating the egoistic will to live, whereas Nietzsche's philosophy is indeed nihilistic, by legitimating the will to power over other living beings. Through his interpretation of Darwinism, Nietzsche showed the actual foundation of Hobbes' homo homini lupus and of ancient Greek sophistic philosophy: the continuation of preying within the human species itself.

Humanistic, subjectivist, modern metaphysics was realized by Nietzsche into the self-legitimation of the will to power (Heidegger 1961).

Lambs are the paradigm of meekness, of the peaceful, non-violent way of living as outlined by Christianity. Thus, when one says that God is incarnated in Jesus and Jesus is presented as the Lamb of God because he was accused and imprisoned for his attack on the Temple in order to free lambs, doves and other sacrificial animals (Matthew 21:1213; Mark 11:15-18; John 2:14-17), and because he was brought as a lamb to the slaughter (Isaiah 53:7), one can also say that God incarnates into a Lamb: the Lamb is the living example of God as Cosmic Love for every creature. Other verses and other texts confirm this interpretation of the Gospel of Jesus (Giannetto 2005; 2006; 2012, 22-33; 2013, 7589). Let us analyze the translation of the Aramaic text of Matthew 18:1-14 (Miniscalchi Frizzo 1861; Wilson 2003):

\begin{abstract}
${ }^{1}$ At the same time came the disciples unto Jesus, saying, Who is the greatest in the kingdom of heaven ${ }^{2}$ And Jesus called a lamb unto him, and set him in the midst of them, ${ }^{3}$ And said, Verily I say unto you, Except ye be converted, and become as lambs, ye shall not enter into the kingdom of heaven. ${ }^{4}$ Whosoever therefore shall humble himself as this lamb, the same is greatest in the kingdom of heaven. ${ }^{5}$ And whoso shall receive one such lamb in my name receiveth me. ${ }^{6}$ But whoso shall do evil to one of these little creatures which have faith in me, it were better for him that a millstone were hanged about his neck, and that he were drowned in the depth of the sea. ${ }^{7}$ Woe unto the time-world because of evils! for it must needs be that evils come; but woe to that man by whom the evil cometh! [... ${ }^{10}$ Take heed that ye despise not one of these little creatures; for I say unto you, That in heaven their angels do always behold the face of my Father of heaven. ${ }^{11}$ For the Son of man is come to save that which was lost. ${ }^{12}$ How think ye? if a man have an hundred sheep, and one of them be gone astray, doth he not leave the ninety and nine, and goeth into the mountains, and seeketh that which is gone astray? ${ }^{13}$ And if so be that he find it, verily I say unto you, he rejoiceth more of that sheep, than of the ninety and nine which went not astray. ${ }^{14}$ Even so it is not the will of your Father of heaven, that one of these little creatures should perish (Matthew 18:1-14).
\end{abstract}

In contrast to the usual translation from the Greek text, here the reference is not to a human child or human children, but to lambs. The Palestinian and Syriac Aramaic term is talià which indicates without any doubt a lamb as it does in Hebrew and Biblical 
Aramaic (Isaiah 40:11 and 65:25). The Greek translation pais is at the very least generic, as it indicates a small creature, and is more probably anthropocentric. The influence of the Greek translation is such that Syriac Aramaic lexicons often do not record "lamb" as a possible meaning for talià, leaving "child" as the only option. The relevance of the lamb symbolism for Jesus in the New Testament confirms this translation; the following verses, expressing care for sheep, are further confirmation. We can also find evidence that the Aramaic text is the original one because of the wordplay, which is lost in the Greek text: "alà...talià...la taloùn" ("except ... lamb... ye shall not enter"). The paradox of Jesus's answer lies in the fact that he upturns all hierarchy, even of species, in such a way that a small creature such as a lamb becomes the greatest in the Kingdom of God. The term usually translated with "to offend" in fact means "to do evil" or "to kill". Even lambs, Jesus says, have angels who protect them!

\title{
10. Blessing All Living Beings
}

Now we may give a new reading of the Aramaic blessing of Jesus (Matthew 5:3-12, Luke 6:20-23, Qs8, Diatessaron):

\begin{abstract}
${ }^{3}$ Blessed are those living beings who are poor in spirit: for theirs now shall be the kingdom of heaven. ${ }^{4}$ Blessed are those living beings that mourn: for they now shall be comforted. ${ }^{5}$ Blessed are those living beings who are meek and humble: they now shall inherit the earth. ${ }^{6}$ Blessed are those living beings which do hunger and thirst with righteousness: they now shall be filled. ${ }^{7}$ Blessed are those living beings who are merciful: they now shall obtain mercy. ${ }^{8}$ Blessed are those living beings who are pure in heart: they now shall see God. ${ }^{9}$ Blessed are those living beings who are peacemakers: they now shall be called the children of God. ${ }^{10}$ Blessed are those living beings which are persecuted and preyed for righteousness' sake: theirs now shall be the Grace of heaven. ${ }^{11}$ Blessed are ye, when men shall revile you, and persecute you, and shall say all manner of evil against you falsely, for my sake. ${ }^{12}$ Rejoice, and be exceeding glad: great now shall be the Grace over you in heaven: for so persecuted they the prophets which were before you.
\end{abstract}

These words are the opening of the so-called "Sermon on the Mount" attributed to Jesus, and they are present even in the most ancient sources of the Gospels: the Gospel of Matthew, source $\mathrm{Q}$ and the Diatessaron. These words are blessing (Aramaic tuvà) words. In some languages, they are interpreted as wish-words of happiness: this is a misleading mistake, because Christian ethics is not eudemonistic like Greek ethics, it does not have the egoistic goal of happiness. Christian happiness can imply personal suffering for the happiness of other beings, for the realization of the Kingdom of God, where justice is realized for all living beings, where no evil shall be present and all creatures shall live together in peace, like the wolf and the lamb, and without any devouring (Isaiah 11:6-9). Blessing does not imply the goal of a reward. This interpretation of the blessing words of Jesus is also influenced by translations from the Tanakh or Ancient Testament or even 
from Qumran texts in terms of wishes of happiness (Siracides or Ecclesiastic. 14:1-2 and 20-27, 15:1-10; Qumran verses 4Q418 81:14, 4Q525 2:1-10, 1QH VI:2-5). There is no for as a final clause of the blessing in the Aramaic text, no logic of egoistic reward. The Christian Palestinian Aramaic text has a fundamental adverb neglected in Greek translations: now. That is, the future is just now: the Kingdom of God shall be here and now! Eschatological fulfillment is just now: no quietism, no waiting for a supernatural paradise. These misleading translations were the fruit of the process of Hellenization and Platonization of Christianity, which grants happiness in the celestial future after death. The immediate actualization of the Kingdom of God is a revolutionary upturning of the hierarchies of ethnicity, of sex, of economic and social class, of political and religious power, of species. No woe is present into the original text: when Jesus says (Luke 6:28) "Bless them that curse you", it is evident that the verses in Luke 6:24-26 must be regarded as later additions (interpolations) due to a vindicating spirit different from that expressed by Jesus.

However, the greatest misleading mistake in translation was to give a purely human connotation to the subjects of Jesus's blessing. These words of blessing could well be the most important words of our Western culture, and their meaning was obscured by anthropocentrism and speciesist ideologies. For too long has Christianity been reduced to an anthropocentric and speciesist doctrine, but Nietzsche understood it in one respect: it is a philosophy of lambs.

Now we can truly understand the blessing of Jesus in a revolutionary way: only

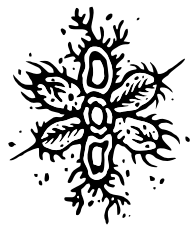
verses 11-12 have a specific human connotation. The reference to poor beings (5:3) is first of all to the fowls of the air and the lilies of the field, who do not accumulate wealth. The reference to beings that mourn (5:4) is first of all to the non-human animals who suffer oppression, exploitation, murder and devouring. The reference to inheriting the Earth (5:5) is first of all to the meek and humble living beings such as lambs or calves, because human beings have torn the Earth from them. The reference to hunger and thirst $[5: 6)$ is not an abstract desire for justice, but rather a call to the living beings which eat and drink in justice, which do not eat flesh and do not drink the blood of other animals. The reference to merciful beings (5:7) is to the living beings which have pity for the suffering of others and take care of them, which do not prey and do no kill. Purity of heart (5:8) is contrasted with the purity required for the Temple sacrifice of non-human animals. The reference to peacemakers (5:9) is to the living beings which do not prey upon and do not devour other animals, beings like lambs which already live as dictated by Isaiah 1:6-9 and 65:25, which describe the so-called messianic peace.

If we share the speciophilosophy of lambs and not that of wolves, we shall be able to engage in dialogue with all other living beings. And we shall be able to produce the required switching of the genes of carnivorism by feeding plant-based food to carnivorous animals for a due time, as dictated by evo/devo (evolution/development) dynamics (Giannetto 2010, Chapter 17). Symphilosophein shall be like when Albert Schweitzer played the organ 
in the African forest and the voices of birds and other animals sang along with it.

\section{References}

Acampora R. R. 2006. Corporal Compassion: Animal Ethics and Philosophy of Body.

Pittsburgh: University of Pittsburgh Press.

Acampora D. \& Acampora R. R. 2003 (Eds.). A Nietzschean Bestiary: Becoming Animal

Beyond Docile and Brutal. Lanham: Rowman \& Littlefield.

Ascher M. 1991. Ethnomathematics: A Multicultural View of Mathematical Ideas. New

York: CRC Press.

Asin y Palacios (Ed.). 1988/1990. Logia et Agrapha Domini Jesu - Apud moslemicos

scriptores, asceticos praesertim, usitata (Series: Patrologia Orientalis; Vol. 13, III;

Vol. 19, IV). Turnhout: Brepols.

Bailey J. 1996. After Thought. New York: Harper Collins.

von Balthasar H. U. 1973. Theodramatik. Freiburg: Einsiedeln.

Beck B. B. 1980. Animal Tool Behavior. The Use and Manufacture of Tools by Animals. New York: Garland.

Bisconti M. 2008. Le culture degli altri animali. Bologna: Zanichelli.

Blumenberg H. 1974. Die Legitimität der Neuzeit (Extended Edition). Frankfurt am Main: Suhrkamp Verlag.

Bonner J. T. 1983. The Evolution of Culture in Animals. Princeton: Princeton University Press.

Böchenhoff J. 1970. Die Begegnungs-Philosophie. Ihre Geschichte - Ihre Aspekte. Freiburg - München: Alber.

Buber M. 1984. Das dialogische Prinzip ( $3^{\text {rd }}$ Edition). Heidelberg: Schneider.

Calarco M. 2008. Zoographies: The Question of the Animal from Heidegger to Derrida. New York: Columbia University Press.

Calogero G. 1985. “Introduzione”, in idem, Scritti minori di filosofia antica (pp. 175-228).

Bibliopolis. (Reprinted from Il Simposio di Platone, pp. 1-74, by G. Calogero, Ed., 1928, Laterza).

Calogero G. 1933. Compendio di storia della filosofia. Firenze: La nuova Italia.

Calogero G. 1936. "Parmenide e la genesi della logica classica," Annali della Regia Scuola

Normale Superiore di Pisa (Series II, Vol. 5, pp. 143-185), Pisa.

Calogero G. 1947. Saggi di Etica e di teoria del diritto. Bari: Laterza.

Calogero G. 1950. Logo e dialogo. Milano: Edizioni di Comunità.

Calogero G. 1960. Lezioni di Filosofia ( $2^{\text {nd }}$ Edition). Torino: Einaudi.

Calogero G. 1962. Filosofia del dialogo. Milano: Edizioni di Comunità. 
Calogero G. 1968. I fondamenti della logica aristotelica (2 ${ }^{\text {nd }}$ Edition). Firenze: La Nuova Italia.

Calogero G. 1977. Studi sull'eleatismo ( $2^{\text {nd }}$ Edition). Firenze: La Nuova Italia.

Calogero G. 2012 (Orig. 1967). Storia della logica antica. Edited by B. Centrone. Pisa: ETS.

Carey N. 2011. The Epigenetics Revolution: How Modern Biology is Rewriting our Understanding of Genetics, Disease and Inheritance. London: Icon Books.

Casper B. 2002. Das dialogische Denken. Franz Rosenzweig, Ferdinand Ebner und Martin Buber. Freiburg - München: Alber.

Colli G. \& Montinari M. (Eds.). 1980. Sämtliche Werke: kritische Studienausgabe. München - Berlin - New York: Deutscher Taschenbuch Verlag/de Gruyter.

Deleanu D. (Ed.). 2002. The Islamic Jesus - The Portrait of Jesus in Islamic Literature and Tradition. Lincoln: Club Press.

Derrida J. 2006. L'animal que donc je suis. Paris: Galilée.

De Santillana G. \& von Dechend H. 1969. Hamlet's Mill. An Essay on Myth and the Frame of Time. Boston: Gambit.

Eisler R. 1951. Man Into Wolf - An Anthropological Interpretation of Sadism, Masochism, And Lycanthropy. London: Spring Books.

Erickson P. I. 2008. Ethnomedicine. Long Grove: Waveland Press.

Feuerbach L. 1866. Das Geheimnis des Opfers oder der Mensch ist, was er isst. In Sämmtliche Werke (Vol. X, pp. 1-35). Leipzig: Wigand.

Feuerbach L. 1975 (Orig. 1866). Werke in sechs Bänden, Band 4: Kritiken und Abhandlungen III (1844-1866). Edited by E. Thies. Frankfurt am Main: Suhrkamp Verlag.

Garfield J. L. \& Edelglass W. 2014. The Oxford Handbook of World Philosophy. Oxford: Oxford University Press.

Giannetto E. 2005. Saggi di Storie del Pensiero Scientifico. Bergamo: Sestante per Bergamo University Press.

Giannetto E. 2006. Vangelo di Giuda. Traduzione dal copto e commento. Milano: Medusa.

Giannetto E. 2010. Un fisico delle origini. Heidegger, la Natura e la scienza. Roma: Donzelli.

Giannetto E. 2011. "Robert Eisler e l'origine della violenza nel carnivorismo," in M. Doni \& E. Gianetto (Eds.), Uomo lupo. Saggio sul sadismo, il masochismo e la licantropia (pp. 13-29). Milano: Medusa.

Giannetto E. 2012. "La Natura come persona," Animal Studies 1:22-33.

Giannetto E. 2013. “Notes for a Metamorphosis,” Society and Animals 21(1):75-89.

Heidegger M. 1950. Holzwege. Frankfurt am Main: Klostermann.

Heidegger M. 1957. Der Satz vom Grund. Pfullingen: Neske.

Heidegger M. 1959. Unterwegs zur Sprache. Pfullingen: Neske.

Heidegger M. 1961. Nietzsche. Pfullingen: Neske. 
Heidegger M. 1977 (Orig. 1927). Sein und Zeit. Edited by F. W. von Herrmann. Tübingen: Niemeyer.

Heidegger M. 1983. Die Grundbegriffe der Metaphysik - Welt - Endlichkeit - Einsamkeit. Frankfurt am Main: Klostermann.

Heidegger M. 2001. Sein und Zeit (18 ${ }^{\text {th }}$ Edition). Tübingen: Niemeyer.

Holzer E., Crusius O., \& Nestle W. 1913. Philologica. Leipzig: Kröner.

Hountondji P. J. 1996. African Philosophy. Myth and Reality (2 $2^{\text {nd }}$ Edition). Bloomington: Indiana University Press.

Husserl E. 1954 (Orig. 1936). Die Krisis der europäischen Wissenschaften und die transzendentale Phänomenologie. Edited by W. Biemel. Den Haag: Nijhoff.

Kant I. 1787. Critik der reinen Vernunft ( $2^{\text {nd }}$ Edition). Riga: J. F. Hartknoch.

Kearney M. 1984. World View. Novato: Chandler \& Sharp.

Kierkegaard S. 2016 (Orig. 1849). The Lily of the Field and the Bird of the Air: Three Godly Discourses. Edited by B. H. Kirmsse. Princeton: Princeton University Press.

Laland K. N. \& Galef B. G. 2009. The Question of Animal Culture. Harvard: Harvard University Press.

Leroi-Gourhan A. 1964. Le geste et la parole: I. Technique et langage. Paris: A. Michel. Linzey A. 1994. Animal Theology. London: SCM Press.

Lukacs G. 1923. Geschichte und Klassenbewusstsein. Studien über marxistische Dialektik. Berlin: Malik.

Malinowski B. 2013. Argonauts of the Western Pacific: An Account of Native Enterprise and Adventure in the Archipelagoes of Melanesian New Guinea (Enhanced Edition). Long Grove: Waveland Press.

Marcuse H. 1955. Eros and Civilisation. A Philosophical Inquiry into Freud. Boston: The Beacon Press.

Miniscalchi Frizzo F. (Ed.). 1861. Evangeliarium Hierosolymitanum - Ex Codice Vaticano Palestino (Volumes 1-2). Veronae: Vicentini et Franchini.

Nietzsche F. 1980 (Orig. 1886). Jenseits von Gut und Böse - Vorspiel einer Philosophie der Zukunft. In G. Colli \& M. Montinari (Eds.), Sämtliche Werke: kritische Studienausgabe. München - Berlin - New York: Deutscher Taschenbuch Verlag/de Gruyter.

Nietzsche F. 1980 (Orig. 1887). Zur Genealogie der Moral, Eine Streitschrift. In G. Colli \& M. Montinari (Eds.), Sämtliche Werke: kritische Studienausgabe. München - Berlin - New York: Deutscher Taschenbuch Verlag/de Gruyter.

Oehler R., Oehler M., \& Freidrich C. 1924. Gesammelte Werke. München: Musarion.

Osha S. 2011. Postethnophilosophy. Amsterdam: Brill \& Rodopi Editions.

Pulak B. \& Chandan S. 2005. Ethnophilosophy: Understanding Northeast India. Bombay: Bhatkal \& Sen.

Radin P. 2003. Primitive Man as Philosopher ( $2^{\text {nd }}$ Revised Edition). Mineola: Dover Publications. 
Rowlands M. 2008. The Philosopher and the Wolf: Lessons from the Wild on Love, Death and Happiness. London: Granta Books.

Scheps R. \& Arom S. (Eds.). 1993. La science sauvage. Des savoirs populaires aux ethnosciences. Paris: Points.

Schweitzer A. 1923. Kulturphilosophie. München: Beck.

Sebeok T. A. 1991. A Sign Is Just a Sign. Bloomington: Indiana University Press.

Sefa Dei G. J. (Ed.). 2011. Indigenous Philosophies and Critical Education: A Reader. New York: Peter Lang.

Sefa Dei G. J., Hall B. L., \& Goldin Rosenberg D. (Eds.). 2000. Indigenous Knowledges in Global Contexts: Multiple Readings of Our World. Toronto: University of Toronto Press.

Small I. (Ed.). 2005. The Complete Works of Oscar Wilde. Oxford: Oxford University Press. Wilde O. 2005 (Orig. 1897). "De Profundis," in I. Small (Ed.), The Complete Works of Oscar Wilde. Oxford: Oxford University Press.

Wilson I. (Ed.). 2003. The Old Syriac Gospels (Vols. 1-2). Piscataway: Gorgias Press.

Worsley P. 1997. Knowledges: How Different Cultures View the World. London: Profile Books. 